International Journal of Social Science And Human Research

ISSN(print): 2644-0679, ISSN(online): 2644-0695

Volume 05 Issue 01 January 2022

DOI: 10.47191/ijsshr/v5-i1-05, Impact factor-5.586

Page No: 25-32

\title{
Determination of Rice Prices to the Welfare of Petani in West Sumatra Province
}

\author{
Lili Salfina ${ }^{1}$, Zaki $^{2}$, Meirinaldi ${ }^{3}$, Sumarni ${ }^{4}$, Elsya Meida Arief ${ }^{5}$ \\ ${ }^{1,2}$ Student University of Borobudur,Jakarta, Indonesia \\ ${ }^{3,4,5}$ Lecturers University of Borobudur, Jakarta, Indonesia
}

\begin{abstract}
The study aims to analyze the influence of rice production, crop dry grain prices (GKP), rice consumption, per capita income and the number of people moderated by rice prices that impact on farmers' well-being. This research method uses a quantitative approach with panel data. The study was conducted in West Sumatra Province in 19 districts / cities with secondary data from the Central Statistics Agency (BPS) of West Sumatra Province in 2013 - 2019. Data analysis uses multiple line regression with panel data.

Simultaneous and partial research results found that rice production, crop dry grain prices (GKP), rice consumption, per capita income, and population can have a significant and positive effect on rice prices in West Sumatra province. While the impact of rice prices has a significant and negative effect on the welfare of farmers in West Sumatra province. The price of dry grain harvest (GKP) is the main factor that affects the price of rice, where rice consumption is a contributing factor that affects the price of rice. Meanwhile, rice production, per capita income and population, is a variable factor of disruption, because rice consumption is influenced by income / purchasing power and the number of family members, and in addition when viewed from the impact, the price of rice has a significant and negative effect on the welfare of farmers.
\end{abstract}

KEY WORDS: Rice production, Dry grain harvest prices, rice consumption, per capita income, population, rice prices and farmer welfare.

\section{INTRODUCTION}

At the moment globally, many countries are in crisis. One potential crisis that has a serious impact is the threat of a global food crisis. The issue ofworld food crisisis closely related to the issue of global climate change andglobaleconomic dynamics, characterized by economiccrisesin developed countries andvolatility in food and energy prices (Minister of Agriculture, 2012). This global problem must have an influence on domestic and local food security conditions, because currently no country can isolate itself from the world community.

Food is the most essential basic need for humans to sustain life. As a living being, without food man cannot live and live for life and society. In terms of meeting rice needs in Indonesia facing a dilemma between efforts to meet domestic consumption needs by increasing productivity and rice imports, with efforts to maintain the stability of rice prices to remain affordable by all parties. Rice demand in 2016 to 2019 decreased by 2.7 million tons per year or rice demand in 2013-2019 reached an average of 32.48. While rice offerings from 2016-2019 fluctuated.

Table 1. Rice Demand and Supply Data in Indonesia 2013 - 2019

\begin{tabular}{|l|l|l|l|}
\hline Year & $\begin{array}{l}\text { Population } \\
(\text { (000 people })\end{array}$ & $\begin{array}{l}\text { Demand } \\
\text { Rice (millions of tons) }\end{array}$ & $\begin{array}{l}\text { Rice Offerings } \\
\text { (millions of tons) }\end{array}$ \\
\hline 2013 & 248.818 & 39.00 & 34.00 \\
\hline 2014 & 252.165 & 34.50 & 34.50 \\
\hline 2015 & 255.462 & 33.30 & 43.90 \\
\hline 2016 & 258.705 & 32.30 & 29.18 \\
\hline 2017 & 261.891 & 29.13 & 29.13 \\
\hline 2018 & 265.015 & 29.57 & 33.94 \\
\hline 2019 & 268074 & 29.60 & 31.31 \\
\hline Average & $\mathbf{2 2 0 . 2 9 3}$ & $\mathbf{3 2 . 4 8}$ & $\mathbf{3 3 . 7 0}$ \\
\hline
\end{tabular}

Source: BPS Indonesia (2020) 


\section{Determination of Rice Prices to the Welfare of Petani in West Sumatra Province}

Based on the table above, seen the trend of the population is increasing, demand is not followed by the supply of rice that increases. This will certainly beabig mas, because the main food of the Indonesian population is rice. For West Sumatra,riceproduction, dry grain harvest price (GKP) and rice price are as seen in the table below:

Table 2. Production, dry grain prices and rice prices in West Sumatra Province 2013 - 2019

\begin{tabular}{|l|l|l|l|}
\hline Year & $\begin{array}{l}\text { Rice Production } \\
\text { (thousands of tons) }\end{array}$ & $\begin{array}{l}\text { GKP Price } \\
(\mathrm{Rp} / \mathrm{Kg})\end{array}$ & Price of rice $(\mathrm{Kg})$ \\
\hline 2013 & $2.503,452$ & 4.005 .38 & $9.558,50$ \\
\hline 2014 & $2.519,020$ & $4.300,95$ & $11.712,50$ \\
\hline 2015 & $2.550,609$ & $4.693,56$ & $12.258,02$ \\
\hline 2016 & $2.503,452$ & $4.617,26$ & $12.789,53$ \\
\hline 2017 & $2.824,509$ & $4.615,23$ & $12.976,00$ \\
\hline 2018 & $1.483,076$ & $4.893,82$ & $13.087,00$ \\
\hline 2019 & $1.482,996$ & $4.638,64$ & $14.242,00$ \\
\hline
\end{tabular}

Source: Central Bureau of Statistics 2020 has been processed.

Based on 26the above ndic, it can be seen the difference in the price of dry grain harvest(GKP) with the price ofrice per kilo gram is very much different. This is due to theincrease in the price of Dry Grain Harvest(GKP) atthe farmer level is a"trade off"for farmers. GKP that is too high causes traders or millers to be unwilling to buy it on the grounds that consumers' purchasing power of rice is low. In this condition, farmers' grain is threatened not to sell because the price is too high, on the other hand, the price is too low, making farmers lose money because the selling price cannot cover production costs.

To improve the welfare of farmers various types of production incentives for farmers have been provided by the government, including in the form of providing land and irrigation infrastructure, development of agricultural tools and machinery services (alsintan), input subsidies (fertilizers, seeds), interest subsidies on agricultural business loans, and other incentives (Simatupang and Rusastra 2004), including price policies. output. Structured output price policy began in 1967 in the form of basic price policy (HD) or floor price of grain and rice (Sawit 2001) which in subsequent years changed in accordance with the economic and political dynamics of national rice in its time. Starting in 2001, the output price policy changed from HD to the basic price of government purchase (HDPP), then to government procurement price (Suryana et al.2001; BKP 2014a).

The price of rice on the market is one of 26the ndicators that affects the per capita income of farmers. According to Mosher (1987), the most important thing about this income is the impact on the welfare of farmers, because some aspects of household welfare depend on income levels. The higher the household income, the percentage of income for food will be reduced. In other words, if there is an increase in income and the increase does not change consumption patterns then the household is prosperous. Conversely, if an increase in household income can change the consumption pattern, it is said to be not prosperous. Research on rice prices is Alan Dwi Wibowo et al., (2015), Nongnooch, Poramacom, (2014), Hezekiah Respatiadi and Hana Nabila (2018), Deby Ananda Difah et al., (2019), Yogi Makbul et al (2019) and Purbiyanti et al., (2017).

This study aims to find out the dominant factors in the determination of rice prices in West Sumatra from the selected variables, namely rice production, rice consumption, community per capita income and population. In connection with the determination of rice prices, it is studied how much the price of rice can affect the welfare of rice farmers.

\section{LITERATURE REVIEW}

The price ofeconomic theory is determined by the intersection between the demand and supply of goods and services in the right. Thus the price of a good and the number of goods sold can be determined by looking at the state of balance in a market (Sukirno, 2013). While Suparyanto and Rosad (2015) stated that the price is a sum of money or something in other forms that has the necessary value to obtain a product. While Rahardja and Manurung (2006) explained the price of agricultural products with teori Cobweb. Cobweb theory is one of the applications of supply-demand analysis that explains why the prices of some agricultural and livestock goods show certain fluctuations from season to season and the cause of these fluctuations is the "late" reaction on the part of producers to prices (Budiono; 2014). According to Wawan Hermawan (2017) research; domestic rice prices are influenced by rice production, rupiah exchange rate, international rice prices and gdp per capita. While Yogi Makbul and Sudrajati Ratnaningtyas (2017) statedthat the price of rice is integrated with the price of riceand Adeniyi, B. A et al., (2019) regarding determinants of rice price volatility. Besides that, the season also affects the price of rice, where in the dry season the rice harvest will be better when compared to the rainy season

Production is a process in which resources (inputs) are processed in such a way as to produce products (output) with greater added value than the previous form (Sukirno 2013). Millers and Meiners (2000) states that production isnot only limited to its manufacture but also storage, distribution, transportation, repackaging, and repackaging or otherwise. Factors of production consist of land, labor, capital and skills, and in agriculture other factors that determine the results of production are also nature. The 


\section{Determination of Rice Prices to the Welfare of Petani in West Sumatra Province}

relationship between factors of production (input) and production output (output) is known as the production function. The production function that is often used is the Cobb-Douglasproductionfunction. Factors affecting production are carried out by Khairul Fahmi Purba et al., (2020). I Made Yoga Prasada (2018) and Abdul Bashir and Saadah Yuliana (2018).

Consumption is the total expenditure to obtain goods and services in an economy in a certain period of time and to get these goods and services in need of income. While according to Mankiw (2013) consumption has the meaning of spending on goods and services by households. John Maynard Keynes in 1930 proposed the theory of consumption that the amount of consumption today is directly related to income. The small amount of consumption carried out is very dependent on income, so it is said that consumption is a function of income (consumption $=\mathrm{f}$ (income)). Menurut Sadono Sukirno (2013) 27the determinant in consumption activities is thebenefits that have beencollected,sku bunga,skufrugal,economiceconomy,distribusi income and not sufficient 27ndicat funds. The results of Rahmasuciana's research, et al., (2015) stated that per capita consumption is influenced byrice prices, per capita income, and consumer preferences. While A. Husni Malian et al., (2004); Rising rice prices will affect household consumption. While Imam Asngari (2020) and Corryati Wardani (2019) reviewed rice consumption.

Per capita income is the average income of the population of a ndica or region in a certain period that is usually one year (Sukirno, 2013). While Jhingan (2007) states that per capita income is the result of sharing between regional income on a constant price basis (ADHK) with a mid-year population. Per capita PDRB can be viewed on the basis of prevailing prices as well as on the basis of constant prices. Percapita is often used as a measure of the prosperity and level of development of a four country or region or determinant of the economic state of a country. According to Kamil Maitah et al., (2020) rice as a determinant of economic sustainability.

Population is the main resource that has a major influence on development in a region based on the Population Reference Bureau (PRB) (2011). And according to BPS (2020), penduduk is all people who are domiciled in the territory of the Unitary State of the Republic of Indonesia for 1 year or more or those domiciled less than 1 year but aim to settle. Based on Malthus'theory, population growth according to the series of measurements and economic growth according to the series ofcalculations, means that the population will grow faster than economic growth (Edmund Conway, 2015).

Community welfare is a number of satisfactions obtained by a person from the results of consuming income received, but the level of welfare itself is something that is ndicato because it depends on the amount of satisfaction obtained from the results of consuming that income. With regards to agriculture, then what is seen is the welfare of farmers. According to Sudana et al., (2008), the welfare of farmers was analyzed using five indicators, namely (1) household income structure (onfarm, off farm, and non farm), (2) Household expenditure structure, (3) Household food subsistence level, (4) Farmer household purchasing power level, and (5) Farmer Exchange Rate (NTP). Nevertheless, this study only conducted an analysis of farmers' exchange rates (NTP). While Ruauw (2010) inhis research discusses about the welfare of farmers is with the Farmer Exchange Rate (NTP). The level of welfare of farmers' households can be approached by the concept of Farmer Exchange Rate (NTP) which is the ratio of the price index received and the index of prices paid by farmers. Thefarmer's household income exchange rate (NTPRP) is as follows:

$$
\mathrm{NTPRP}=\mathrm{Y} / \mathrm{E} \mathrm{Y}=\mathrm{YNP}+\mathrm{YP} \mathrm{E}=\mathrm{EP}+\mathrm{EK}
$$

Where:

$\mathrm{YP}=$ Total exposure from agricultural business

YNP = Total Revenue from non-agricultural businesses

$\mathrm{EP}=$ Total expenditure for agricultural businesses

EK = Total expenditure for non-agricultural businesses

The results of research from Emily Schmidt (2020) stated that the price of rice induced by Covid 19 has an impact on the welfare of the community.

\section{METHODS Of RESEARCH}

The method of data analysis in this study is descriptive and verifiative analysis. Verifiive analysis in this study uses regression analysis of panel data (pooleddata). Data panel is combining cross sectional data with time series. Cross sectional data is the number of districts and cities in West Sumatra Province and Time Series is the time period from 2013 to 2019. The data processing tools in this study used Microsoft excel and Eviews 10software. Regression determination is done through the stages of determining the estimation model (Pooled OLS / Common Effect, Fixed Effect and Random Effect) by means of the F (Tast Chow) test, Hausman test, and Lagrange Multiplier test. The next step is the F test hypothesis, and the t test and coefficient of determination. A frame of mind formed based on the following images: 


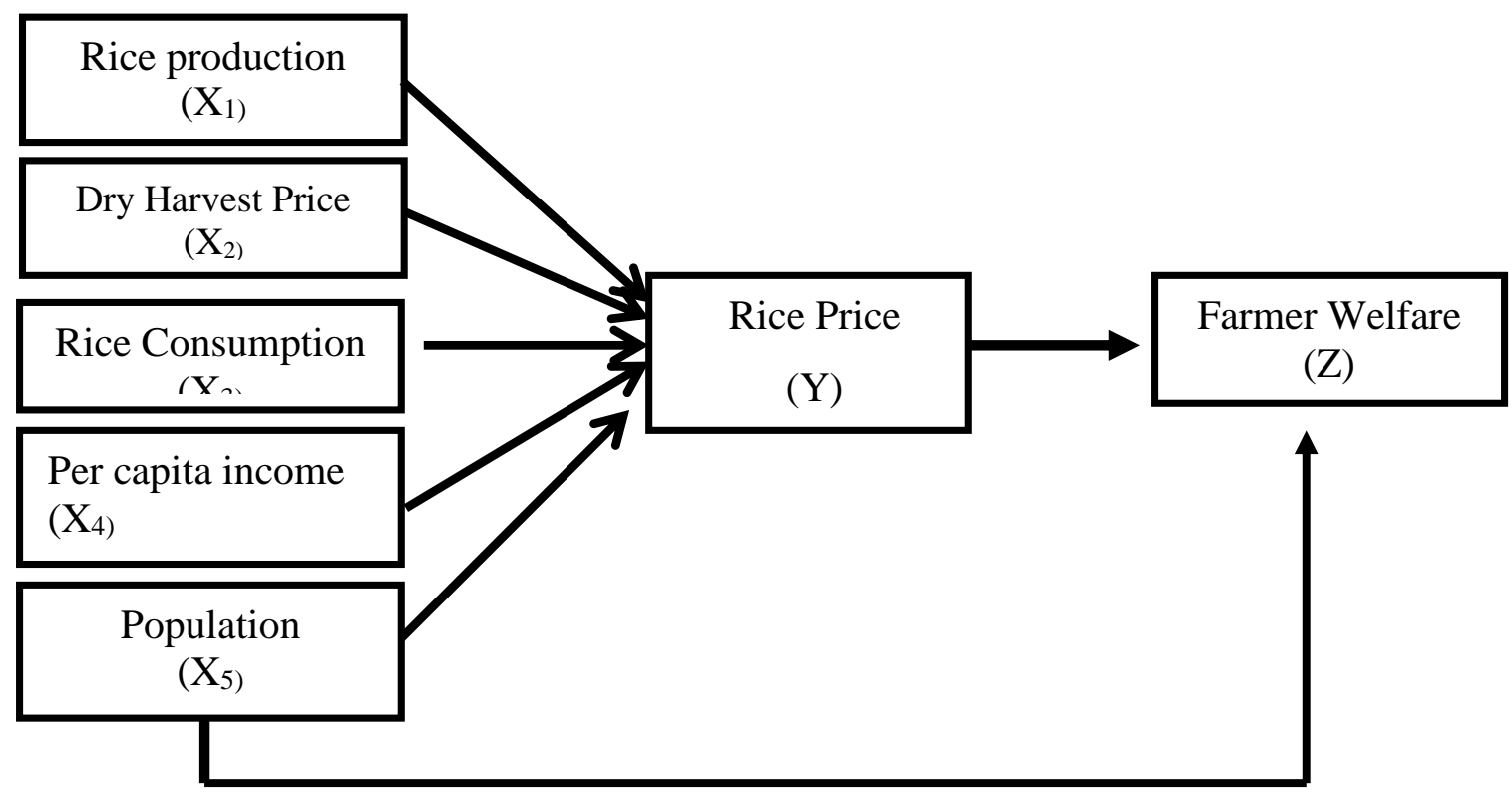

Figure 1. Research Scheme

Based on the above frame of mind, two equations are obtained as follows:

Equation 1: The effect of rice production, the price of dry grain harvest, rice consumption, per capita income and the population on the price of rice.

$$
\mathbf{Y}_{\text {it }}=\alpha+\beta_{1} \mathbf{X}_{1}+\beta_{2} \mathbf{X}_{2}+\beta_{3} \mathbf{X}_{3}+\beta_{4} \mathbf{X}_{4}+\beta_{5} \mathbf{X}_{5}+\varepsilon i t
$$

Where:

$\mathrm{Y}_{\text {it }} \quad=$ Price of rice

$\alpha=$ Constant

$\beta=$ Regression coefficient of each independent variable

$\mathrm{X}_{1} \quad=$ Rice production

$X_{2} \quad=$ Price of dry grain harvest

$X_{3} \quad=$ rice consumption

$X_{4} \quad=$ income per capita

$X_{5} \quad=$ population

$\varepsilon \quad=$ Error term

$\mathrm{t} \quad=$ Time

$\mathrm{i} \quad=$ Regency/city

Equation 2: The price of rice has an impact on the welfareoffarmers.

$$
\mathbf{Z}_{\mathbf{i t}}=+\boldsymbol{\beta} \boldsymbol{Y}_{i t}+\varepsilon_{i t}
$$

Where:

$\mathrm{Z}_{\mathrm{it}}=$ Farmer Welfare

$\alpha=$ Constant

$\beta=$ Regression coefficient

$\mathrm{Y}_{\mathrm{it}}=$ Price of rice

\section{RESULTS AND DISCUSSION}

Geographically, West Sumatra Province is located between 98o 36'-101o 53' East Longitude and 0 o 54' North Latitude up to 3o 30' South Latitude, with a land area of $+42,297.30 \mathrm{Km} 2$ and water area (sea) $+51,060.23 \mathrm{~km} 2$ with a land area coastline length +375 $\mathrm{Km}$ plus the length of the Coastline of the Mentawai Islands $+1,003$ so that the total overall coastline $+1,378 \mathrm{Km}$. These sea waters have 185 large and small islands. Administratively, West Sumatra Province consists of 19 regencies / cities (12 regencies and 7 cities) which have 179 sub-districts with 259 villages and 760 nagari, with the following boundaries: north with North Sumatra province, east with Riau and Jambi provinces, south with Bengkulu province, and west border with the Indian Ocean according to rpjmd information from West Sumatra (2009 - 2029).

The hydrological condition of West Sumatra Province has considerable water resources when viewed from the number of rivers and lakes. The number of rivers in West Sumatra Province reaches 606 rivers that partly empties into the Indian Ocean on the 


\section{Determination of Rice Prices to the Welfare of Petani in West Sumatra Province}

West Coast and partly towards the East Coast of Sumatra Island. West Sumatra area that is fed by this river can be divided into 9 Units of River Region (SWS) namely SWS Akuaman, Siberut Island, Natal-Batahan, Kampar, Batang Hari, Silaut, Rokan, Indragiri and Masang. The source of the river water comes from mountains and lakes (Lake Above, Lake Below, Lake Maninjau and Lake Singkarak). Lake Singkarak located in Solok regency and Tanah Datar has an area of 13,011 km2, Lake Maninjau is located in Agam Regency has an area of 9,950 km2, while Lake Above (3,150 km2), Lake Below (1,400 km2), and Lake Talang (1.02 km2) are found in SolokRegency.

West Sumatra consists of 12 regencies and 7 municipalities. Those included in the district include K. Mentawai, South Coast, Solok Regency, Swl / Sijunjung, Tanah Datar, Padang Pariaman, Agam,50 Kota, Pasaman, Solok Selatan, Dhamasraya, West Pasaman. While the municipalities are Padang, Solok, Sawah Lunto, Padang Panjang, Bukit Tinggi, Payakumbuh and Pariaman.

Based on the test results in determining the best model is the Fixed Effect shown by the results of processed eviws 10 as follows:

Table 3.

\begin{tabular}{|c|c|c|c|c|}
\hline \multicolumn{5}{|c|}{$\begin{array}{l}\text { Dependent Variable: LOGY } \\
\text { Method: Panel Least Squares } \\
\text { Date: 03/07/21 Time: } 16: 12 \\
\text { Sample: } 20132019 \\
\text { Periods included: } 7 \\
\text { Cross-sections included: } 16 \\
\text { Total panel (balanced) observations: } 112\end{array}$} \\
\hline Variable & Coefficient & Std. Error & t-Statistic & Prob. \\
\hline $\mathrm{C}$ & 6.377946 & 0.352267 & 18.10544 & 0.0000 \\
\hline LOGX1 & 0.053930 & 0.003161 & 17.06218 & 0.0000 \\
\hline LOGX2 & 0.092173 & 0.033329 & 2.765557 & 0.0069 \\
\hline LOGX3 & 0.091974 & 0.041299 & 2.227018 & 0.0284 \\
\hline LOGX4 & 0.055198 & 0.015192 & 3.633450 & 0.0005 \\
\hline LOGX5 & 0.057676 & 0.005338 & 10.80420 & 0.0000 \\
\hline$\overline{\mathrm{R} \text {-squared }}$ & 0.969899 & F-statistic & & 146.6062 \\
\hline Adjusted R-squared & 0.963283 & Prob(F-statistic & & 0.000000 \\
\hline
\end{tabular}

Source: in olah with eviews 10

Equation: 1 is:

$$
\begin{aligned}
\log Y=6.377946+ & 0.053930 \log X_{1}+0.092173 \log X_{2}+0.091974 \log X_{3} \\
& +0.055198 \log X_{4}+0.057676 \log X_{5}+\text { ei }
\end{aligned}
$$

Equation 1 above can be interpreted that:

- Constant a of 6.377946 states that if the value of variables $\mathrm{X} 1, \mathrm{X} 2, \mathrm{X} 3, \mathrm{X} 4, \mathrm{X} 5$ is constant (0) thenthe variable value Harga rice $(\mathrm{Y})$ is 6.377946 and the relationship that occurred is positive and significant.

- The regression coefficient value X1 (rice production) has a positive relationship to the price of rice withthe value of the betacoefficient $=0.053930$ meaning that every $1 \%$ increase in rice production,then the price of rice $(\mathrm{Y})$ will increase by $0.054 \%$, dnature this other factor is considered fixed and the relationship that occurs is significant.

- The regression coefficient value X2 (Price Gabah Kering Petani) has a positive relationship with the price of rice with a beta coefficient $=0.092173$ meaning that every increase of $1 \% \mathrm{X} 2$, then the price of rice $(\mathrm{Y})$ will increase by $0.092 \%$, dnature this other factor isconsidered The relationship and the relationship is significant. The price of dry grain harvest (GKP) is the main factor affecting the price of rice addressed by the beta coefficient of 0.0922 .

- Regression coefficient value X3 (Rice consumption) has a positive relationship with the value of the beta coefficient $=0.091974$ meaning that every $1 \%$ increase in rice consumption,then the price of rice(Y)will increase by $0.0920 \%$, dnaturethis other factor is considered fixed and the relationship that occurs is significant. Kounces of rice is a contributing factor that affects the price of rice after the price of dry grain at the farmer level.

- The regression coefficient value X4 (per capita income) has a positive relationship of 0.055198 which means that every increase of $1 \%$ per capita income, then the price of rice $(\mathrm{Y})$ will increase by $0.055 \%$, dnature this other factor is consideredfixed and the relationship that occurs is significant. 


\section{Determination of Rice Prices to the Welfare of Petani in West Sumatra Province}

- The regression coefficient value X5 (Population) has a positive relationship of 0.057676 which means that every change of $1 \%$ of the population,then the price of rice $(\mathrm{Y})$ will decrease by $0.058 \%$, dnature this other factor is consideredfixed andthe relationship that occurs is significant.

Hasyl test $\mathrm{f}$ (simultaneous influence) on equation 1 is rice production (X1), dry grainharvest price(X2), rice consumption(X3), percapita income (X4) and population number (X5) is significant and positive the price of rice with a Prob (F-statistic) value of 0.0000. And the Coefficient of Determination is expressed in the form of Adjusted R-Squared results of 0.963283 which means that rice production, dry grain harvest prices, rice consumption, per capita income and population together have an effect of $96.3 \%$ on rice prices. 3.7\% was influenced by other factors that were not included in the study. In addition, the form of variable relationship X (riceproduction, dry grain harvest price, rice consumption, per capita income and population) to the price of rice $(\mathrm{Y})$. is in elastic (elasticity < 1), this relationship states that the large treatment of variable $\mathrm{X}$ (riceproduction, dry grain harvest price, rice consumption, per capita income) and the population) has only a small impact on the price of rice (Y).

Based on the test results in determining the best model is the Fixed Effect shown by the results of processed eviws 10 as follows:

Table 4. Model Panel Data Regression Results 2

Dependent Variable: LOGZ1

Method: Panel Least Squares

Date: 03/07/21 Time: 16:22

Sample: 20132019

Periods included: 7

Cross-sections included: 19

Total panel (balanced) observations: 133

\begin{tabular}{lllll}
\hline \hline Variable & Coefficient & Std. Error & t-Statistic & Prob. \\
\hline \hline C & 7.281212 & 0.068390 & 106.4665 & 0.0000 \\
LOGY & -0.285290 & 0.007255 & -39.32273 & 0.0000 \\
\hline \hline R-squared & 0.931898 & F-statistic & 81.38299 \\
Adjusted R-squared & 0.920447 & Prob(F-statistic) & 0.000000 \\
\hline \hline
\end{tabular}

Source: Output Eviews Statistics Version 10

The 2nd equation in this study is

$$
\log Z=7.281212-0.285290 \log Y
$$

The form of equation obtained from the selection of models that have been done chow test, Hausman test and Lagrange Multiplier test is a Random Effect model. From the results of the equation obtained the following:

- Constant $(\alpha)$ of 7,281212 states that if the Price of Rice(Y) does not undergo treatment then the variable value of farmer welfare (KP) is 7,281212 .

- The regression coefficient value $Y$ has a negative relationship with a beta coefficient of 0.285290 which means that every $1 \%$ increase in the price of rice $(\mathrm{Y})$,then the welfare of farmers $(\mathrm{Z})$ will decrease by $0.29 \%$, in which case other factors areconsidered fixed.

The effect of rice prices $(\mathrm{Y})$ on the welfare of farmers $(\mathrm{Z})$ is negative and significant,while the magnitude of the effect of riceprices $(\mathrm{Y})$ on the welfare of farmers $(\mathrm{Z})$ is shown by the results adjusted $R$-Squared is 0.931898 . This means that $93.1 \%$ of the variable rice price $(Y)$ affects the welfare of farmers, whilethe remaining6.9\% is influenced by other variables outside the study variable. The form of relationship between rice prices and the welfare of farmers is elastic which means that large changes to rice prices have only a small impact on the welfare of farmers (the price of rice at the high consumer level causes a decrease in farmers' welfare to decrease, although the decrease is notas big as the increase in riceprices).

\section{CONCLUSION}

In West Sumatra the price of rice is adilemma, because it mustbe a farmer or riceconsumer. The price of rice will affect the level of wisdom of farmers. Thisstudy tried to observe the influence of rice prices and their effect on the welfare of farmers in 12 regencies and 7 municipalities in West Sumatra. 


\section{Determination of Rice Prices to the Welfare of Petani in West Sumatra Province}

The results stated that all the variables used in this study had a positive and significant effect on the price of rice, although the effect was inelastic. In addition, the price of rice with a negative and significant level of farmer welfare which means that the increase in rice prices has an impact on the decrease in the level of farmer welfare.

In connection with the results of research, the increase in rice prices at the consumer level has a negative influence on the welfare offarmers. This contradicts existing theories, wherethe price of rice at the consumer level is determined by adry grain at the farmerlevel. One of the causes of the decline in the level of welfare of farmers is the increase in rice prices at the consumer level is much higher than the price ofdry grain at thefarmer level. In addition, price increases at the consumer level can lead to inflation. And this is what causes the level of welfare of farmers to decline. According to Deby Ananda Difah (2019); thewidening price of rice at the farmer level and the retail price of rice indicates an asymmetrical vertical price transmission.

The improvement of farmers' welfare by the Regional Government of West Sumatra Province is carried out by ensuring price stability and increasing rice production through guaranteeing food availability by protecting farmers from rice imports, encouraging increased rice production domestik,maintaining the availability of irrigation and agricultural inputs, strengthening the availability of foodstuffs to meet population consumption inWest Sumatera province, in addition to doing so. kan rice price policythat favors farmers.

\section{REFERENCES}

1) Adeniyi, B. A., Amao, O., Daud, S. A., and Omotoso, A.B (2019), Econometric Analysis of Determinants of Rice Price Volatility in Nigeria (1970-2017), The International Journal of Engineering and Science (IJES), Volume: 8 Issue: 11 Series II,p. 20-25.

2) Abdul Bashir and Saadah Yuliana (2018), Identifying Factors Influencing Rice Production and Consumption in Indonesia, Journal of Development Economics: Study of Economic and Development Problems, 19 (2), p. 172-185.

3) Alan Dwi Wibowo, Armand Omar Moei, Candra B. Wigunab, T. A.C. Chaulan (2015), Policy model of production and price of rice in South Kalimantan, The 2014 International Conference on Agro-industry (ICoA): Competitive and sustainable Agroindustry for Human Welfare, Agriculture and Agricultural Science Procedia 3, p. 266 - 273

4) Boediono (2014), Microeconomics. Yogyakarta: BPFE

5) Corryati wardani (2019), Determinant Of Rice Consumption: Evidence From Panel Data In Indonesia, International Journal Of Mechanical Engineering And Technology (Ijmet), Volume 10, Issue 05, P. 160-168.

6) Deby Ananda Difah, Harianto, and Dedi Budiman Hakim (2019), Rice Price Transmission In Indonesia: Threshold Cointegration Approach, Journal of Food System and Agribusiness Vol. 3 (2),p. 31-39.

7) Emily Schmidt, Paul Dorosh, Rachel Gilbert (2020), Impacts of COVID-19 induced income and rice price shocks on household welfare in Papua New Guinea: Household model estimates, Agricultural Economics. , ;52,p. :391-406.

8) Edmund Conway (2015),50 Economic Ideas You Need to Know, Essence of Erlangga Group, Jakarta

9) I Made Yoga Prasada, Aura Dhamira, Agus Dwi Nugroho (2018), Supply Response of Paddy in East Java: Policy Implications to Increase Rice Production, AGRARIS: Journal of Agribusiness and Rural Develpoment Research, Vol. 4 No. 2,p. 130-138.

10) Imam Asngari, Suhel Suhel1, Abdul Bashir, Andi Nurul A. Arief, Era Susanti (2020), Rice Consumption Pattern of Rural Households in East OKU and South OKU Regencies South Sumatra Province Indonesia, International Journal of Economics and Financial Issues, 10(1), p. 259-265.

11) Jhingan, M.L. (2007). Economic Development and Planning. Jakarta: King GrafindoPersada.

12) Hezekia Respatiadi and Hana Nabila (2018), Policy Options to Lower Rice Prices in Indonesia, Scientific Bulletin of Trade R\&D, Vol. 12 no. 1, p. 95-115.

13) Husni Malian (2004) Kebijakan Perdagangan Internasional Komoditas Pertanian Indonesia. Pusat Penelitian dan Pengembangan Sosial Ekonomi Pertanian. AKP Vol 2.

14) Kamil Maitah, Luboš Smutka, Jeta Sahatqija , Mansoor Maitah and Nguyen Phuong Anh (2020), Sustainability 2020, 12,5123; doi:10.3390/su12125123,p. 1-12.

15) Khairul Fahmi Purba, Muhammad Yazid, Mery Hasmeda, Dessy Adriani, Meitry Firdha Tafarini, Technical Efficiency And Factors Affecting Rice Production In Tidal Lowlands Of South Sumatra Province Indonesia, Potravinarstvo Slovak Journal of Food Sciences vol. 14, p. 101-111

16) Miller, Roger LeRoy and Roger E. Meiners, (2000). Microeconomics Intermediate Theory, Jakarta: PT Raja GrafindoPesada.

17) Mankiw, N. G. (2013.). Introduction to Macroeconomics, Jakarta: Publisher Salemba Four.

18) Mosher AT. 1987. Mobilizing and building agriculture the basic conditions of development and modernization. Translation from: Getting agriculture moving. Jakarta (ID): CV Yasaguna

19) Nongnooch Poramacom, PhD (2014), Rice Production, Prices and Related Policy in Thailand, International Journal of Business and Social Science, Vol. 5, No. 10(1),p. 201-210. 


\section{Determination of Rice Prices to the Welfare of Petani in West Sumatra Province}

20) Prathama Rahardja. Manurung, Mandala (2006). Teori Ekonomi Mikro Suatu Pengantar, Edisi Ketiga, Jakarta; Lembaga Penerbit Fakultas Ekonomi Universitas Indonesia.

21) Purbiyanti, E., Muhammad, Y., \& Indri, J. (2017). Conversion of rice fields in Indonesia and its effect on the Government Purchase Price (HPP) policy of grain / rice. Journal of Management \& Agribusiness, 14(3), 209- 217

22) Rahmasuciana, D. Y., \& Darwanto, D. H. (2015). Terhadap Harga Beras Dalam Negeri, 26(2).

23) Ruauw, E. (2010), “Nilai Tukar Petani Sebagai Indikator Kesejateraan Petani.” Universitas Samratulangi, Manado. ASE 6 (2): p. $1-8$

24) Sadono, Sukirno. (2013). Macroeconomic Theory Introduction. Jakarta: PT. Rajagrafindo Persada.

25) Simatupang, Pandjar; Mardianto, Sudi and Maulana Mohamad.( 2005). Evaluation of Grain Price Policy 2004. Agricultural Policy Analysis Vol. 3 No. 1, 2005 p. 1-11. www.pse.litbang.deptan.go.id

26) Suparyanto \& Rosad. (2015). Manajemen Pemasaran, In Media, Yogyakarta

27) Suryana, A. dan S. Mardianto. (2001). Bunga Rampai Ekonomi Beras. Tim Pengkajian Kebijakan Perberasan Nasional dan Lembaga Penyelidikan Ekonomi dan Masyarakat, Fakultas Ekonomi, Universitas Indonesia, Jakarta. 266 hlm

28) Wawan Hermawan, Fitrawaty, Indra Maipita (2017), Factors Affecting the Domestic Price of Rice in Indonesia, Jejak Vol 10 (1),p. 155-171.

29) Yogi Makbul (2019), Integration of Rice Prices at Producer, Wholesaler, and Urban and Rural Consumer Markets with Paddy Prices at the Farm Gate, Archives of Business Research - Vol.7, No.3, p. 1-11.

30) Yogi Makbul and Sudrajati Ratnaningtyas and Pradono Pradono (2017), Integration of Rice Prices at Producer, Wholesaler, and Urban and Rural Consumer Markets with Paddy Prices at the Farm Gate, Archives of Business Research - Vol.7, No.3, p.1-11 